\title{
Tamara Jacka, Rural Women in Urban China: Gender, Migration and Social Change.
}

\section{Sally Sargeson}

\section{Q OpenEdition}

12 Journals

Édition électronique

URL : http://journals.openedition.org/chinaperspectives/4872

DOI : $10.4000 /$ chinaperspectives.4872

ISSN : 1996-4617

Éditeur

Centre d'étude français sur la Chine contemporaine

\section{Édition imprimée}

Date de publication : 1 septembre 2009

ISSN : 2070-3449

\section{Référence électronique}

Sally Sargeson, « Tamara Jacka, Rural Women in Urban China: Gender, Migration and Social

Change. », China Perspectives [En ligne], 2009/3 | 2009, mis en ligne le 16 octobre 2009, consulté le 21 septembre 2020. URL : http://journals.openedition.org/chinaperspectives/4872 ; DOI : https://doi.org/ 10.4000/chinaperspectives.4872

Ce document a été généré automatiquement le 21 septembre 2020.

(C) All rights reserved 


\title{
Tamara Jacka, Rural Women in Urban China: Gender, Migration and Social Change.
}

\author{
Sally Sargeson
}

1 China's "urban revolution" has become the focus of a large body of literature in recent years. But while much of the new urbanisation literature builds on earlier research into the roles played by rural-urban migration in propelling urban population growth, challenging urban governance institutions and practices, and diversifying urban cultures, there has been relatively little attention given to the gender analysis agenda that undergirded and enriched some of the best studies of rural-urban migration. Those studies clearly demonstrated that migration is gender-specific and has gender outcomes. For example, compared to urbanites of both sexes and rural men, rural women tend to have fewer years of education. They therefore are considered to be not only "less competitive" in urban labour markets, but also significantly more vulnerable to abuse and exploitation. Biological assumptions underpin different moral and behavioural standards for migrant men and women. Likewise, as married women are presumed to bear responsibility for social reproduction and care, they manage most of the physical, social, and emotional logistics necessitated by the dispersal of household members.

2 Thus, it seems timely to reconsider how one of the major studies of rural women's experience of migration advanced our understanding of not only women's migration, but also how women's migration reconfigures gender in China's growing cities. Tamara Jacka's Rural Women in Urban China: Gender, Migration and Social Change was one of the first and remains one of the most insightful examinations of migrant women in contemporary urban space. The book is prefaced by an examination of how images of "rural idiocy" continue to be counterposed to projections of "urban modernity" in state policy rhetoric and media reports on migration. Although pointing to the progressivist functions served by these tropes, Jacka also shows how they feed anxieties and ambivalent desires among the gendered subject category of "rural migrant women." 
3 In the substantive chapters that follow, conversations with migrant women in Hangzhou in 1995 and interviews, observation, and a small survey conducted in Beijing between 2001 and 2002 provide the empirical material with which Jacka produces a nuanced, sympathetic depiction of migrant women's multi-faceted public image and discursive positioning over time, relational space, and place.

4 The analysis in Chapter Two of whether the Migrant Women's Club in Beijing constitutes "'a subaltern counter public' - a space where migrant women assemble and perform oppositional interpretations of their identities and interests - or whether they have merely reproduced the hierarchies of dominant discourses" is one of the most interesting sections of the book. Created in 1996 under the aegis of the All-China Women's Federation, the club on the one hand pioneered efforts to articulate and further the interests of women as migrants. On the other hand, it is clear that the club's objectives, campaigns, and activities were underpinned and hence limited in their effectiveness by rural-urban and gender hierarchies. The primary discourse around which the Club initially "assembled" migrant women was that these women were the vulnerable but malleable subjects of urban agents and their modernist, civilising projects.

5 In 2001, following a major restructuring, the focus of the club shifted from improving individual women's quality, or suzhi, to identifying the social-structural sources of their disadvantage and performing pastoral functions. Notwithstanding these adjustments, however, like other quasi-non-governmental domestic organisations affiliated with China's mass organisations, the club continued to subsume concerns about gender inequality under the "demands" of the urban economy. Yet although the migrant women who used the club were to some extent susceptible to these hierarchical modernist discourses, their critical assessments of the club and the fact that they "voted with their feet" indicates that they were by no means passive subjects shaped by or resisting their leaders. Contemporary analyses of the effects of urban governance in constraining social discontent by promoting homogenous national narratives of modernisation and private lifestyle consumption would do well to attend to the sources and expressions of ambivalence, dissatisfaction, and heterogeneity among the migrant women highlighted by Jacka.

6 The subsequent sections of the book examine how women's migration experiences and migrant identities are "emplaced." Institutionally, of course, the residential registration system and urban housing and job markets disadvantaged Jacka's interlocutors, but Jacka navigates beyond these familiar analytical territories. Resisting crude analytical categories such as "place of origin" and "life course," Jacka illuminates the material, social, and imaginative topographies over which young single women and older married women moved. Differently positioned in temporal and relational space, "filial" and "rebellious" daughters, flirts, and doubting and dutiful wives are motivated by radically different assessments and desires to move to the city. Depicting villages as places where "there was nothing to do," young women's stories of why they leave "connote not just inactivity and the boredom that goes with it but also a sense of worthlessness." But for them, the city serves not simply as a foil to the village, a counter-site in which activity, inspiration, and esteem are bound up with trajectories of "personal development." Rather, it simultaneously stimulates youngsters' romantic longings, wants, and needs, and their valorisation of the significance of autonomy in relationships. For many older married women, the city is envisaged strategically as the 
nexus for flows (of remittances, people, knowledge, and services) and hence, the tool with which they might realise intergenerational interdependence and development. These gendered relational and temporal understandings of urban place cross-cut simple patterns of inclusion/exclusion produced by modes of governance, or social or class hierarchies deriving from rural-urban institutions.

7 In short, this book opens the way to understanding urbanisation as a gendered process, one that is propelled not only by top-down policy decisions, competitive rescaling of metropolitan jurisdictions and land markets, and government activity, but also by the diverse populations of men and women who, in the course of lodging in and travelling through urban places, transform how gender relations are performed in, and configure, city spaces. 